\title{
INTERAKSI DEMOKRATIS DALAM PEMBELAJARAN EKSPLORATIF MODEL HOTL-DI TIPE A FENOMENA NYIUR MELAMBAI
}

\author{
Falenty Claudia Matulessy, Christophil Medellu, Jimmy Lolowang \\ Fakultas Matematika dan Ilmu Pengetahuan Alam, Universitas Negeri Manado \\ email: matulessyfalenty0798@gmail.com
}

\begin{abstract}
ABSTRAK
Fenomena alam sekitar membentuk pengalaman beragam pada siswa. Ragam pengalaman dan persepsi yang terbentuk dalam struktur kognitif, dapat diintegrasikan dengan pembelajaran formal di kelas sehingga diperoleh penguatan hubungan konteks-konsep, ataupun perbaikan miskonsepsi yang bersifat individual. Tujuan penelitian ini adalah mengeksplorasi konsep dan proses sains fenomena nyiur melambai atau pohon kelapa yang berayun ketika ditiup angin. Penelitian ini menggunakan pendekatan kualitatif dan kuantitatif. Penelitian dilaksanakandi jurusan fisika FMIPA unima. Hasil penelitian menunjukkan bahwa pelibatan mentor dapat membangun komunikasi terbuka antar mahasiswa dalam kelompok maupun antara mahasiswa mentor dengan kelompok sasaran. Kerjasama dan perilaku demokratis terlihat pada saat mahasiswa melakukan kegiatan eksplorasi dengan baik, sehingga pembelajaran ini dapat mewujudkan pembelajaran aktivitas mengeksplorasi objek atau konteks, konsep dan proses sains fenomena nyiur melambai.
\end{abstract}

Kata kunci: Pembelajaran eksploratif, Interaksi demokratis, Peran mentor, Fenomena nyiur melambai

\begin{abstract}
Natural phenomena around form a religious experience in students. The variety of experiences and perceptions that are formed in the cognitive structure can be integrated with formal learning in the classroom in order to strengthen the context-concept relationship or improve individual misconceptions. The purpose of this research is to explore the concept and scientific process of the phenomenon of waving palm trees or coconut trees that swing when blown by the wind. This research uses qualitative and quantitative approaches. The research was carried out in the physics department of FMIPA Unima. The results showed that the involvement of mentors can build open communication between students in groups and between student mentors and the target group. Cooperation and democratic behavior can be seen when students carry out exploration activities well, so that this learning can realize learning activities to explore objects or contexts, concepts and scientific processes of waving palm phenomena.
\end{abstract}

Keywords: Explorative learning, Democratic interaction, The role of mentor, Palm waving phenomenon 


\section{PENDAHULUAN}

Sains adalah ilmu yang mempelajari fenomena alam dan mengungkap fenomena yang ada dibaliknya menggunakan metode ilmiah. Sains merupakan suatu ilmu atau pengetahuan yang sudah tersusun secara sistematis dengan adanya beberapa aspekaspek alam (Muspiroh, 2016). Sains tersusun secara sistematis, yang mencakup proses untuk memperoleh pengetahuan dalam memahami suatu lingkungan hidup dan masalah-masalah yang dihadapi oleh peserta didik saat ini sehingga sangat bergantung pada kemajuan ilmu pengetahuan dan teknologi melalui pengamatan,berpikir dan bekerja ilmiah.

Fisika adalah bangun pengetahuan yang menggambarkan usaha, temuan, wawasan dan kearifan yang bersifat kolektif dari umat manusia (Wartono, 2003).

Objek utama dalam pembelajaran fisika adalah alam. Salah satu gejala alam yang dapat kita jadikan sebagai objek pembelajaran fisika adalah pohon kelapa (nyiur melambai). Proses eksplorasi dapat membuat peserta didik menganalisis dan mengidentifikasi konsepkonsep fisika pada pohon kelapa karena alam sekitar sudah menanamkan pengalaman pada peserta didik, sehingga dalam mengamati dan menganalisis objek di alam membuat peserta didik merasa tertarik melakukan kegiatan eksplorasi. Memanfaatkan sumber dari alam sekitar dalam kegiatan pembelajaran, memungkinkan peserta didik agar lebih menghargai, mencintai, serta melestarikan lingkungan alam sekitar sebagai kehidupannya. (Usman, 2012).

\section{KAJIAN LITERATUR}

Johari (2013) menjelaskan bahwa kegiatan eksplorasi, guru melibatkan siswa dalam mencari dan menghimpun informasi dengan menggunakan media untuk memperkaya pengalaman, memfasilitasi peserta didik berinteraksi sehingga menjadi aktif, mendorong siswa mengamati berbagi gejala, menangkap tanda-tanda yang membedakan dengan gejala pada peristiwa lain. Eksplorasi konsep dan proses sains tentang fakta, fenomena, dan isu-isu di linkungan sekitarnya adalah proses mengintegrasikan pengalaman dunia nyata dengan pembelajaran sains di kelas (Silangen and Medellu, 2019).

Interaksi demokratis merupakan hubungan antara individu dan kelompok yang memiliki persamaan hak dan kewajiban serta perlakuan yang sama. Interaksi demokratis meliputi aktivitas penyampaian hasil belajar berpikir setiap individu yang dapat berbeda dalam memahami, mempersepsi objek atau fenomena (Medellu, 2019).

\section{METODE PENELITIAN}

Jenis penelitian yang digunakan adalah penelitian pembelajaran eksploratif. Penelitian ini dilaksanakan di Jurusan Fisika, Fakultas Matematika dan Ilmu Pengetahuan Alam, Universitas Negeri Manado pada bulan Juli Desember 2019. Objek penelitian ini adalah pohon kelapa (nyiur melambai) dan subjek dalam penelitian ada 2 kelompok, yaitu : (1) mahasiswa Pendidikan Fisika semester V, kelas B Tahun Ajaran 2019-2020, sebagai kelompok uji coba dengan tujuan untuk revisi dan pengembangan materi yang telah dibuat, serta perekrutan mentor bagi kelompok pembelajaran, (2) mahasiswa Fisika semester III Tahun Ajaran 2019-2020, sebagai kelompok penelitian pembelajaran eksploratif.

Penelitian ini termasuk dalam jenis penelitian ekplorasi dengan pendekatan campuran yaitu kualitatif dan kuantitatif. Penelitian ekploratif yang digunakan oleh tim peneliti adalah model HOTL-DI Tipe A yang dirumuskan oleh Medellu 2019.

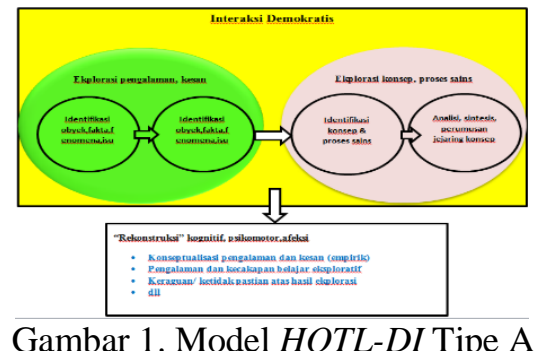

Penelitian ini menggunakan pendekatan campuran yaitu kualitatif dan kuantitatif. Pendekatan ini merupakan pendekatan mix methods yaitu metode yang mengkombinasikan dua bentuk pendekatan dalam penelitian yaitu kualitatif dan kuantitatif sehingga diperoleh data yang lebih valid. Dari proses ekplorasi, peneliti menggunakan pendekatan kualitatif sebagi frame yang dapat berkembang, didalamnya terdapat data kuantitatif yang dijelaskan secara terperinci melalui data kualitatif.

Penelitian ini dilakukan dalam 3 Tahapan utama : 


\section{1) Eksplorasi oleh Tim Peneliti}

Eksplorasi oleh tim peneliti bertujuan memberikan pengalaman pada peneliti untuk melakukan tahapan eksplorasi objek konsep dan proses sains serta menghasilkan referensi matriks ekplorasi yang digunakan peneliti untuk memfasilitasi kegiatan pembelajaran ekploratif pada kelompok uji coba/mentor dan sasaran. Model pembelajaran ekploratif yang digunakan adalah model HOTL-DI Tipe A.

2) Ekplorasi dan Interaksi Demokratis oleh Kelompok Uji Coba

Eksplorasi dan interaksi demokratis oleh kelompok uji coba bertujuan untuk memberikan pengalaman melakukan tahapan ekplorasi secara individual maupun interaksi kelompok, menghasilkan matriks eksplorasi, dan merekrut mentor untuk tahapan selanjutnya. Tim peneliti memberikan Format 1 ekplorasi proses HOTL-DI untuk diisi oleh kelompok uji coba. Pada tahapan ini, tim peneliti berperan sebagai mentor yang mengarahkan kelompok uji coba dalam tahapan mengeksplorasi disertai dengan penilaian interaksi demokratis. Format yang telah diisi kelompok uji coba ditinjau oleh tim peneliti sebagai bahan revisi untuk referensi matriks selanjutnya.

3) Ekplorasi dan Interaksi Demokratis oleh Kelompok Sasaran

Eksplorasi dan interaksi demokratis oleh kelompok sasaran bertujuan untuk memberikan pengalaman melakukan tahapan ekplorasi secara individual maupun interaksi kelompok dan menghasilkan matriks eksplorasi. Tim peneliti memberikan Format 1 eksplorasi proses HOTL-DI untuk diisi oleh kelompok sasaran.

\section{HASIL DAN PEMBAHASAN}

\section{A. Rancangan kegiatan eksplorasi objek konsep dan proses fisika oleh tim peneliti (Kolaborasi)}

Tim peneliti melakukan eksplorasi objek konsep dan proses fisika pada fenomena yang banyak dijumpai dalam kehidupan sehari-hari yaitu nyiur melambai atau pohon kelapa yang berayun ketika ditiup angin. Tempat penelitian di Desa Tountimomor, kec. Kakas dan Desa Sumarayar, kec. Langowan Timur pada bulan Juli-Agustus 2019. Materi pada tabel ekplorasi yang dirancang oleh tim peneliti dengan objekobjek

Tahapan mengeksplorasi dimulai dengan tahap mengidentifikasi fakta dan fenomena objek 1 pohon kelapa tegak dengan analisis deskripsi jika buahnya lebat, pohon kelapa yang tegak akan tetap tegak, dan tanpa pengaruh angin, banyaknya buah kelapa meningkatkan berat bagian ujung pohon kelapa (bagian buah + daun). Eksplorasi konsep dan proses fisika yang terdapat pada objek 1 yaitu : massa batang, pusat massa, dan statika, dengan merumuskan konsep-konsep fisika tersebut pada tahap analisis-sintesis-formulasi.

Mengidentifikasi fakta dan fenomena objek II pohon kelapa miring dengan analisis deskripsi jika buahnya lebat, pohon kelapa yang miring akan semakin bertambah miring, dan tanpa pengaruh angin, banyaknya buah kelapa meningkatkan berat bagian ujung pohon kelapa (bagian buah + daun). Eksplorasi konsep dan proses fisika yang terdapat pada objek 2 yaitu : massa batang, pusat massa, torsi, dan statika, dengan merumuskan konsep-konsep fisika tersebut pada tahap analisis-sintesis-formulasi.

Mengidentifikasi fakta dan fenomena objek III pohon kelapa tegak yang ditiup angin kencang menyebabkan batang berayun dengan analisis deskripsi ketika angina bertiup kencang pohon bertambah miring, dan setelah angina redah pohon kelapa kembali ke posisi awal. Ketika ditiup angin terjadi perpindahan pusat massa. Pohon kelapa akan patah/roboh ketika melebihi batas elastisitas (tergantung pada kuat batang dan akar pohon kelapa). Eksplorasi konsep dan proses fisika yang terdapat pada objek 3 yaitu : massa batang, pusat massa, torsi, dan gaya elastisitas (Pemulih), dengan merumuskan konsep-konsep fisika tersebut pada tahap analisis-sintesis-formulasi. Indikator-indikator yang digunakan dalam penilaian yaitu (1) Berani mengemukakan pendapat. (2) Menghargai pendapat anggota kelompok. (3) Mendorong teman aktif berpartisipasi dalam kelompok. (4) Memberi kritik positif dan memberi penjelasan. (5) Berinisiatif mengaktifkan kegiatan kelompok. (6) Menghargai kritik teman. (7) Disiplin dan bertanggungjawab untuk kesepakan bersama.

(8) Kesediaan menggunakan fasilitas pribadi.

\section{B. Hasil analisis kegiatan eksplorasi oleh} kelompok uji coba

Pada awal berinteraksi dengan kelompok, subjek penelitian masih mengalami kesulitan karena sikap ingin menang sendiri, sikap egois yang muncul pada diri anggota kelompok yang ingin mempertahankan jawabannya masing- 
masing memberi kendala dalam menyatukan satu pendapat menjadi satu pola pikir yang sama. Tahapan ini dilakukan agar mendapatkan suatu gambaran yang baik untuk penelitian selanjutnya. Eksplorasi kelompok uji coba dilakukan dengan 3 kali pertemuan (Objek 1, Objek 2, dan Objek 3). Hasil capaian skor interaksi demokratis tiap langkah Eksplorasi ditunjukkan pada tabel 1,2 dan 3 .

Tabel 1. Langkah eksplorasi objek 1

\begin{tabular}{cccccccccc}
\hline $\begin{array}{c}\text { Langkah } \\
\text { eksplora } \\
\text { si objek }\end{array}$ & \multicolumn{7}{c}{ Rata-rata Indikator interaksi demokratis } \\
\cline { 2 - 9 } 2 & 1 & 2 & 3 & 4 & 5 & 6 & 7 & 8 \\
\hline 2.2 & 4,8 & 4,7 & 4,3 & 4,8 & 4,6 & 4,3 & 5 & 4 \\
\hline 2.3 & 5 & 5 & 4,6 & 4,8 & 4,5 & 4,7 & 4,7 & 4 \\
\hline 2.4 & 5 & 5 & 4,6 & 4,2 & 4,3 & 5 & 4,4 & 4 \\
\hline
\end{tabular}

Tabel 2. Langkah eksplorasi objek 2

\begin{tabular}{cccccccccc}
\hline $\begin{array}{c}\text { Langkah } \\
\text { eksplora } \\
\text { si objek } \\
3\end{array}$ & \multicolumn{6}{c}{ Rata-rata Indikator interaksi demokratis } \\
\hline 3.2 & 4,7 & 5 & 4 & 4 & 5 & 6 & 7 & 8 \\
\hline 3.3 & 4,8 & 4,6 & 4,7 & 4 & 4 & 4,8 & 4 & 4 \\
\hline 3.4 & 4,8 & 5 & 4,9 & 4 & 4 & 4,8 & 5 & 4 \\
\hline
\end{tabular}

Tabel 3. Langkah eksplorasi objek 3

\begin{tabular}{ccccccccc}
\hline $\begin{array}{c}\text { Langk } \\
\text { ah } \\
\text { eksplo } \\
\text { rasi } \\
\text { objek }\end{array}$ & 1 & 2 & 3 & 4 & 5 & 6 & 7 & 8 \\
1 & & & & & & & & \\
\hline 1.2 & 4,5 & 4,3 & 4,5 & 4,5 & 4,3 & 4,8 & 4,6 & 4 \\
\hline 1.3 & 4,5 & 4,3 & 4,3 & 4,6 & 4,3 & 4,7 & 4,5 & 4 \\
\hline 1.4 & 4,5 & 4,6 & 4,7 & 4,4 & 4,5 & 4,7 & 4,3 & 4 \\
\hline
\end{tabular}

Kolom rata-rata skor capaian interaksi demokratis merupakan skor capaian masingmasing indikator yang sudah dirata-ratakan berdasarkan hasil tiap individu dalam kelompok. Kemudian diambil rata-rata untuk setiap indikator interaksi demokrati untuk setiap langkah eksplorasi. Penyajian data pada tabel menunjukkan pencapaian skor interaksi demokratis untuk setiap tahapan eksplorasi. Pada tahap ini direkrut mentor untuk membimbing, mengarahkan, serta menilai proses pembelajaran demokratis pada kelompok sasaran.

\section{Hasil analisis kegiatan eksplorasi oleh kelompok sasaran}

Pembelajaran eksplorasi dilakukan pada mahasiswa semester III sebagai kelompok sasaran. Peran mentor sebagai fasilitator membantu jalannya penelitian pada kelompok sasaran, dengan mentor berjumlah 3 orang. dilaksanakan pada tanggal 11-17 desember 2019, di Jurusan Fisika Unima. Waktu diberikan pada subjek penelitian agar pembelajaran semakin efektif dalam melaksanakan kegiatan pembelajaran eksplorasi yang sedang berlangsung. Pada saat proses interaksi demokratis, kerja sama kelompok serta perilaku demokratis setiap mahasiswa akan dinilai berdasarkan 8 indikator yang telah dibuat oleh tim peneliti berdasarkan grafik untuk setiap indikator 1-8. Pada grafik akan terlihat perkembangan indikator (perilaku demokratis) untuk setiap objek (objek 1, objek 2, dan objek 3) dan tahapan (1.2, 1.3, dan 1.4), dengan skor penilaian 1-5.

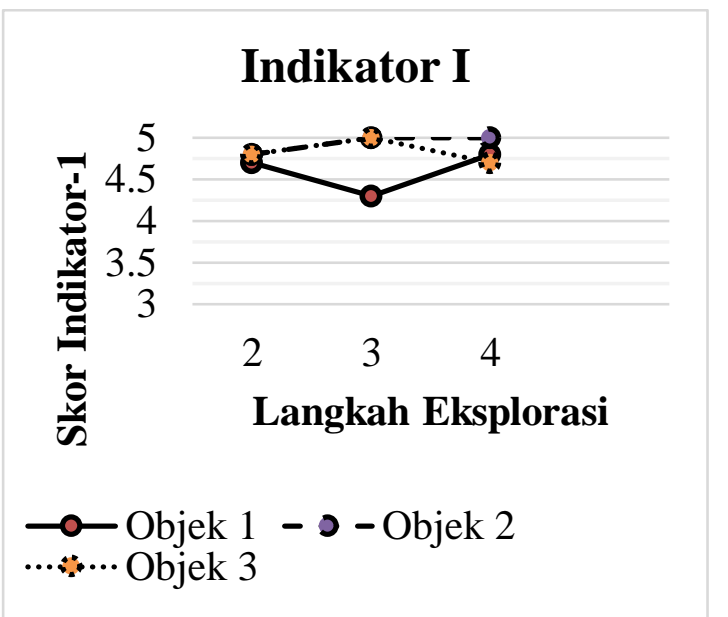

Gambar 2. Intensitas Interaksi Demokratis Indikator 1

Hasil capaian skor interaksi demokratis (Indikator-1) yaitu berani mengemukakan pendapat pada objek 1 (pohon kelapa tegak) di tahap (1.1) tim penelitian telah menyertakan gambar dan keterangan pada tahap ini, subjek penelitian sudah dapat melihat pada gambar dan kemudian mengidentifikasi dan mengeksplorasi objek, sehingga tahap identifikasi tidak dinilai. Pada tahap (1.2) yaitu mendeskripsikan fenomena menunjukkan beberapa anggota kelompok aktif dalam mengemukakan pendapat satu sama lain sudah baik, kemudian grafik terlihat turun di tahap (1.3) yaitu eksplorasi konsep menunjukkan ada beberapa anggota kelompok dalam mengemukakan pendapat terlihat kurang aktif pada tahap ini, kemudian grafik terlihat naik di 
tahap (1.4) dalam merumuskan konsep-konsep fisika menunjukkan anggota kelompok aktif dalam mengemukakan pendapat. Pada objek 2 (pohon kelapa miring) di tahap (2.2) yaitu mendeskripsikan fenomena menunjukkan antar anggota kelompok dalam mengemukakan pendapat satu sama lain sudah baik, kemudian grafik terlihat naik di tahap (2.3) dan (2.4) yaitu ekplorasi konsep dan analisis sintesisformulasi yang menunjukakan anggota kelompok aktif dalam mengemukakan pendapat sudah sangat baik. Pada objek 3 (pohon kelapa berayun) di tahap (3.2) yaitu mendeskripsikan fenomena menunjukkan beberapa anggota kelompok aktif dalam mengemukkan pendapat satu sama lain sudah baik, kemudian grafik terlihat naik di tahap (3.3) yaitu eksplorasi konsep menunjukkan antar anggota kelompok dalam mengemukkan pendapat sangat baik, kemudian grafik turun di tahap (3.4) dalam merumuskan konsep-konsep fisika menunjukkan ada beberapa anggota kelompok kurang aktif dalam mengemukakan pendapat.

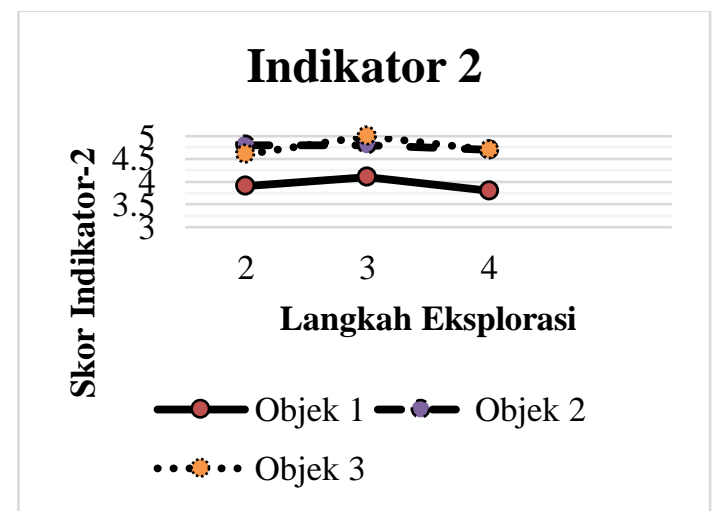

Gambar 3. Intensitas Interaksi Demokratis Indikator 2

Hasil capaian skor interaksi demokratis (Indikator-2) yaitu menghargai pendapat anggota kelompok pada objek 1 (pohon kelapa tegak) di tahap (1.1) tim penelitian telah menyertakan gambar dan keterangan pada tahap ini, subjek penelitian sudah dapat melihat pada gambar dan kemudian mengidentifikasi dan mengeksplorasi objek, sehingga tahap identifikasi tidak dinilai. Pada tahap (1.2) yaitu mendeskripsikan fenomena menunjukkan ada beberapa anggota kelompok kurang menghargai pendapat satu sama lain cukup baik, kemudian grafik terlihat naik di tahap (1.3) yaitu eksplorasi konsep menunjukkan anggota kelompok dalam menghargai pendapat satu sama lain sudah baik pada tahap ini, kemudian grafik turun di tahap (1.4) dalam merumuskan konsep-konsep fisika menunjukkan beberapa anggota kelompok kurang menghargai pendapat anggota kelompok. Pada objek 2 (pohon kelapa miring) di tahap (2.2) yaitu mendeskripsikan fenomena menunjukkan antar anggota kelompok dalam mengemukakan pendapat satu sama lain sudah baik, kemudian grafik terlihat naik dan turun di tahap (2.3) dan (2.4) yaitu ekplorasi konsep dan analisis sintesis-formulasi atau merumuskan konsep yang menunjukakan antar anggota kelompok aktif dalam mengemukakan pendapat sudah baik. Pada objek 3 (pohon kelapa berayun) di tahap (3.2) yaitu mendeskripsikan fenomena menunjukkan beberapa anggota kelompok aktif dalam menghargai pendapat satu sama lain sudah baik, kemudian grafik terlihat naik di tahap (3.3) yaitu eksplorasi konsep menunjukkan antar anggota kelompok dalam menghargai pendapat satu sama lain sangat baik, kemudian grafik turun di tahap (3.4) dalam merumuskan konsep-konsep fisika menunjukkan beberapa anggota kelompok kurang dalam menghargai pendapat satu sama lain.

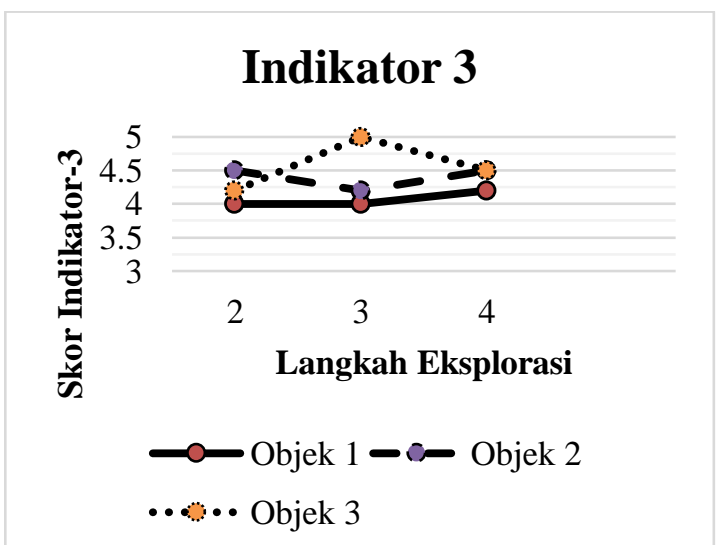

Gambar 4. Intenstitas Interaksi Demokratis Indikator 3

Hasil capaian skor interaksi demokratis (Indikator-3) yaitu mendorong teman aktif berpartisipasi dalam kelompok pada objek 1 (pohon kelapa tegak) di tahap (1.1) tim penelitian telah menyertakan gambar dan keterangan pada tahap ini, subjek penelitian sudah dapat melihat pada gambar dan kemudian mengidentifikasi dan mengeksplorasi objek, sehingga tahap identifikasi tidak dinilai. Pada tahap (1.2) dan (1.3) yaitu mendeskripsikan fenomena dan eksplorasi konsep menunjukkan 
anggota kelompok aktif mendorong teman untuk berpartisipasi sudah baik, kemudian grafik terlihat naik di tahap (1.4) dalam merumuskan konsep-konsep fisika menunjukkan anggota kelompok semakin aktif mendorong teman untuk berpartisipasi dengan hasil baik. Pada objek 2 (pohon kelapa miring) di tahap (2.2) yaitu mendeskripsikan fenomena menunjukkan antar anggota kelompok aktif mendorong teman untuk berpartisipasi sudah baik, kemudian grafik turun di tahap (2.3) yaitu ekplorasi konsep yang menunjukakan beberapa anggota kelompok kurang aktif mendorong teman untuk berpartisipasi, kemudian grafik terlihat naik di tahap (2.4) dalam merumuskan konsep-konsep fisika menunjukkan anggota kelompok semakin aktif mendorong teman untuk berpartisipasi dengan hasil baik. Pada objek 3 (pohon kelapa berayun) di tahap (3.2) yaitu mendeskripsikan fenomena menunjukkan anggota kelompok aktif mendorong teman untuk berparisipasi sudah baik, kemudian grafik terlihat naik di tahap (3.3) yaitu eksplorasi konsep menunjukkan antar anggota kelompok aktif mendorong teman untuk berpartisipasi pada tahap ini sangat baik, kemudian grafik turun di tahap (3.4) dalam merumuskan konsep-konsep fisika menunjukkan beberapa anggota kelompok kurang aktif mendorong teman untuk berpartisipasi.

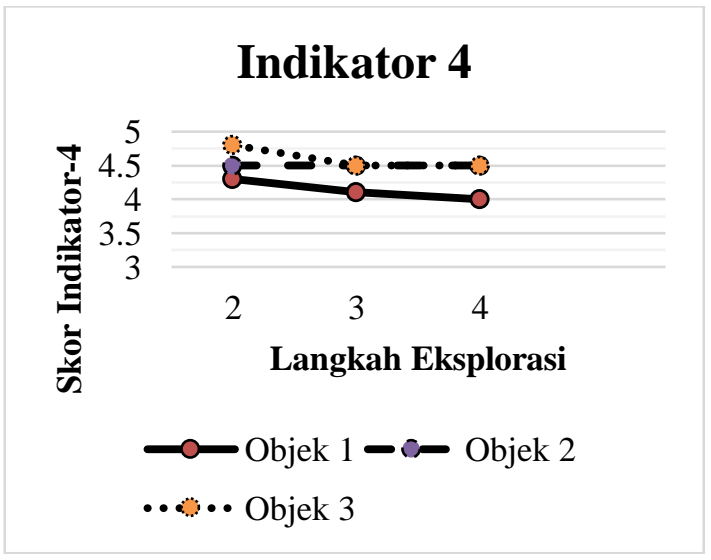

Gambar 5. Intensitas Interaksi Demokratis Indikator 4

Hasil capaian skor interaksi demokratis (Indikator-4) yaitu memberi kritik yang positif pada objek 1 (pohon kelapa tegak) di tahap (1.1) tim penelitian telah menyertakan gambar dan keterangan pada tahap ini, subjek penelitian sudah dapat melihat pada gambar dan kemudian mengidentifikasi dan mengeksplorasi objek, sehingga tahap identifikasi tidak dinilai. Pada tahap (1.2) yaitu mendeskripsikan fenomena menunjukkan anggota kelompok aktif dalam memberi kritik yang positif sudah baik, kemudian grafik turun di tahap (1.3) dan (1.4) fisika yaitu ekplorasi konsep dan merumuskan konsep-konsep yang menunjukakan anggota kelompok dalam memberi kritik yang positif sudah baik. Pada objek 2 (pohon kelapa miring) di tahap (2.2), (2.3), dan (2.4) yaitu mendeskripsikan fenomena, ekplorasi konsep, dan merumuskan konsep-konsep fisika menunjukkan antar anggota kelompok aktif memberi kritik yang positif sudah baik. Pada objek 3 (pohon kelapa berayun) di tahap (3.2) yaitu mendeskripsikan fenomena menunjukkan anggota kelompok aktif memberi kritik yang positif sudah baik, kemudian grafik terlihat turun di tahap (3.3) dan (3.4) yaitu eksplorasi konsep dan merumuskan konsep-konsep fisika menunjukkan beberapa anggota kelompok kurang aktif memberi kritik yang positif pada tahap ini sudah baik.

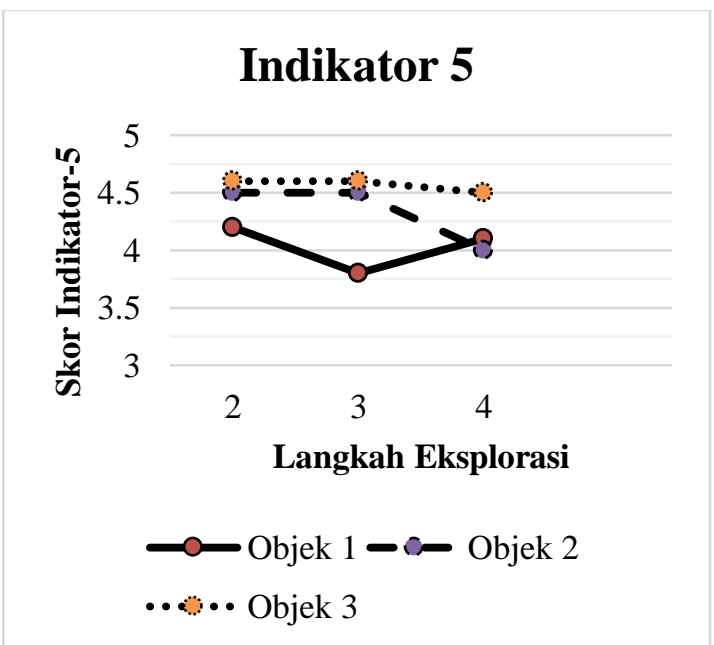

Gambar 6. Intensitas Interaksi Demokratis Indikator 5

Hasil capaian skor interaksi demokratis (Indikator-5) yaitu menghargai kritik teman pada objek 1 (pohon kelapa tegak) di tahap (1.1) tim penelitian telah menyertakan gambar dan keterangan pada tahap ini, subjek penelitian sudah dapat melihat pada gambar dan kemudian mengidentifikasi dan mengeksplorasi objek, sehingga tahap identifikasi tidak dinilai. Pada tahap (1.2) yaitu mendeskripsikan fenomena menunjukkan anggota kelompok menghargai pendapat teman sudah baik, kemudian grafik turun di tahap (1.3) yaitu eksplorasi konsep 
menunjukkan beberapa anggota kelompok cukup baik dalam menghargai pendapat teman. Grafik naik pada tahap (1.4) yaitu merumuskan konsep-konsep fisika menunjukkan beberapa anggota kelompok sudah baik dalam menghargai kritik teman. Pada objek 2 (pohon kelapa miring) di tahap (2.2), dan (2.3) yaitu mendeskripsikan fenomena dan ekplorasi konsep menunjukkan antar anggota kelompok dalam menghargai kritik teman sudah baik, kemudian di tahap (2.4) yaitu merumuskan konsep-konsep fisika terlihat grafik turun dan menunjukkan beberapa anggota kelompok kurang dalam menghargai kritik teman. Pada objek 3 (pohon kelapa berayun) di tahap (3.2) dan (3.3) yaitu mendeskripsikan fenomena dan eksplorasi konsep terlihat grafik naik menunjukkan antar anggota kelompok dalam menghargai pendapat teman sudah baik, kemudian grafik terlihat turun di tahap (3.4) yaitu merumuskan konsep-konsep fisika menunjukkan beberapa anggota kelompok kurang menghargai kritik teman.

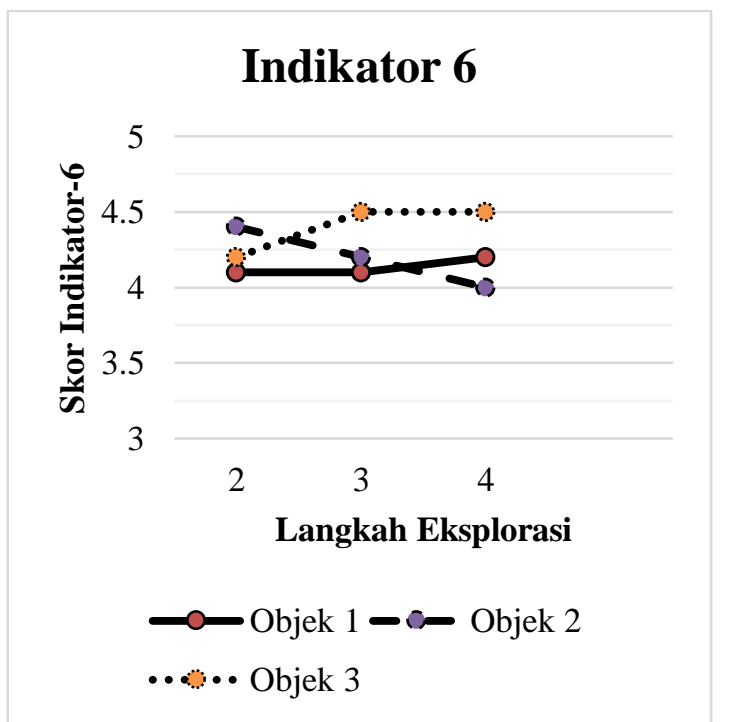

Gambar 7. Intensitas Interaksi Demokratis Indikator 6

Hasil capaian skor interaksi demokratis (Indikator-6) yaitu berinisiatif mengaktifkan kegiatan kelompok pada objek 1 (pohon kelapa tegak) di tahap (1.1) tim penelitian telah menyertakan gambar dan keterangan pada tahap ini, subjek penelitian sudah dapat melihat pada gambar dan kemudian mengidentifikasi dan mengeksplorasi objek, sehingga tahap identifikasi tidak dinilai. Pada tahap (1.2) dan (1.3) yaitu mendeskripsikan fenomena dan eksplorasi konsep menunjukkan anggota kelompok berinisiatif mengaktifkan kegiatan sudah baik,. Grafik naik pada tahap (1.4) yaitu merumuskan konsep-konsep fisika menunjukkan anggota kelompok yang berinisiatif mengaktifkan kegiatan dalam kelompok sudah baik. Pada objek 2 (pohon kelapa miring) di tahap (2.2) yaitu mendeskripsikan fenomena menunjukkan antar anggota kelompok berinisiatif mengaktifkan kegiatan dalam kelompok sudah baik, kemudian di tahap (2.3) yaitu ekplorasi konsep terlihat grafik menurun menunjukkan beberapa anggota kelompok kurang aktif dalam berinisiatif mengaktifkan kegiatan dalam kelompok. Pada tahap (2.4) yaitu merumuskan konsep-konsep fisika terlihat grafik turun dan menunjukkan beberapa anggota kelompok kurang dalam berinisiatif mengaktifkan kegiatan dalam kelompok. Pada objek 3 (pohon kelapa berayun) di tahap (3.2) yaitu mendeskripsikan fenomena menunjukkan antar anggota kelompok berinisiati mengaktifkan kegiatan dalam kelompok sudah baik, kemudian grafik naik di tahap (3.3) dan (3.4) yaitu ekplorasi konsep dan merumuskan konsep-konsep fisika menunjukkan anggota kelompok berinisiatif mengaktifkan kegiatan kelompok sudah baik.

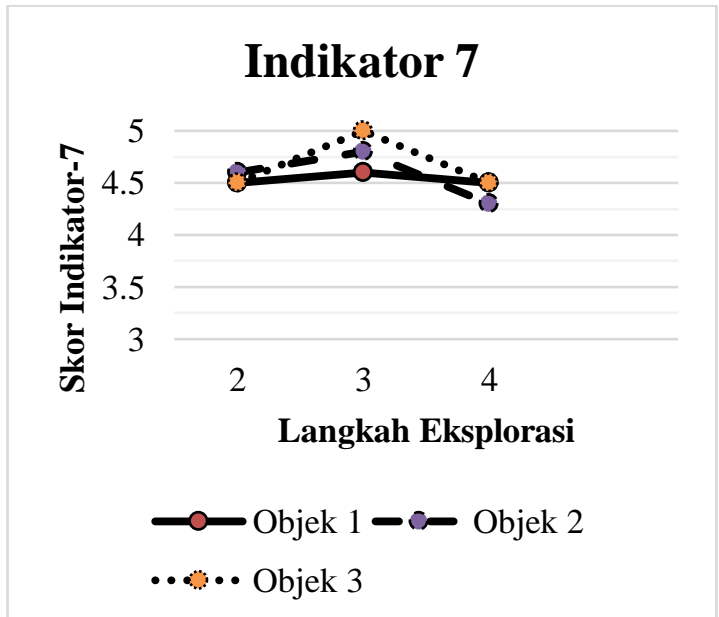

Gambar 8. Intensitas Interaksi Demokratis Indikator 7

Hasil capaian skor interaksi demokratis (Indikator-7) yaitu disiplin dan bertanggungjawab untuk keepakatan bersama pada objek 1 (pohon kelapa tegak) di tahap (1.1) tim penelitian telah menyertakan gambar dan keterangan pada tahap ini, subjek penelitian sudah dapat melihat pada gambar dan kemudian mengidentifikasi dan mengeksplorasi objek, 
sehingga tahap identifikasi tidak dinilai. Pada tahap (1.2) dan (1.4) yaitu mendeskripsikan fenomena dan merumuskan konsep-konsep fisika menunjukkan beberapa anggota kelompok disiplin dan bertanggungjawab untuk kesepakatan bersama sudah baik. Grafik terlihat naik pada tahap (1.3) yaitu eksplorasi konsep menunjukkan anggota kelompok disiplin dan bertanggungjawab sudah baik. Pada objek 2 (pohon kelapa miring) di tahap (2.2) yaitu mendeskripsikan fenomena menunjukkan antar anggota kelompok disiplin dan sudah baik, kemudian di tahap (2.3) yaitu ekplorasi konsep terlihat grafik naik menunjukkan beberapa anggota kelompok disiplin dan bertanggungjawab mengaktifkan kegiatan kelompok sudah baik. Pada tahap (2.4) yaitu merumuskan konsep-konsep fisika terlihat grafik turun dan menunjukkan beberapa anggota kelompok kurang disiplin dan bertanggungjawab untuk kesepakan bersama. Pada objek 3 (pohon kelapa berayun) di tahap (3.2) dan (3.4) yaitu mendeskripsikan fenomena dan merumuskan konsep-konsep fisika menunjukkan antar anggota kelompok disiplin dan bertanggungjawab untuk kesepakatan bersama sudah baik, kemudian grafik naik di tahap (3.3) yaitu ekplorasi konsep menunjukkan anggota kelompok disiplin dan bertanggujawab untuk kesepakatan bersama sudah sangat baik.

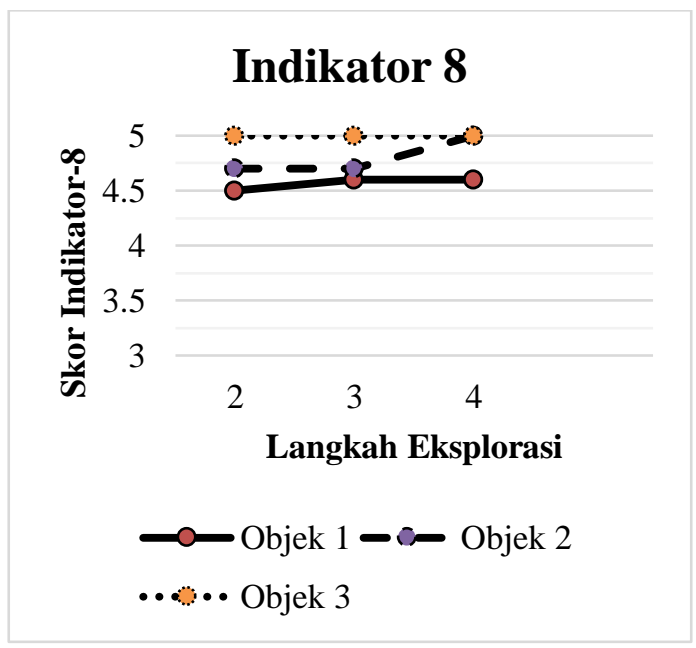

Gambar 9. Intensitas Interaksi Demokratis Indikator 8

Hasil capaian skor interaksi demokratis (Indikator-8) yaitu kesediaan menggunakan fasilitas pribadi pada objek 1 (pohon kelapa tegak) di tahap (1.1) tim penelitian telah menyertakan gambar dan keterangan pada tahap ini, subjek penelitian sudah dapat melihat pada gambar dan kemudian mengidentifikasi dan mengeksplorasi objek, sehingga tahap identifikasi tidak dinilai. Pada tahap (1.2) yaitu mendeskripsikan fenomena menunjukkan kesediaan menggunakan fasilitas pribadi dalam kelompok sudah baik. Grafik naik pada tahap (1.3) dan (1.4) yaitu ekplorasi konsep dan merumuskan konsep-konsep fisika menunjukkan kesediaan menggunakan fasilitas pribadi dalam kelompok meningkat dengan hasil sangat baik. Pada objek 2 (pohon kelapa miring) di tahap (2.2) dan (2.3) yaitu mendeskripsikan fenomena dan ekplorasi konsep menunjukkan beberapa anggota kelompok dalama kesediaan menggunakan fasilitas pribadi meningkat dengan hasil sangat baik, kemudian di tahap (2.4) yaitu merumuskan konsep-konsep fisika terlihat grafik naik dengan pesat menunjukkan kesediaan menggunakan fasilitas pribadi anggota kelompok sangat baik. Pada objek 3 (pohon kelapa berayun) di tahap (3.2) , (3.3), dan (3.4) yaitu mendeskripsikan fenomena, ekplorasi konsep, dan merumuskan konsepkonsep fisika menunjukkan kesediaan menggunakan fasilitas bersama dalam kelompok sangat baik.

\section{KESIMPULAN}

Konsep-konsep fisika yang terdapat pada fenomena nyiur melambai, antara lain : massa batang, pusat massa, gaya berat, hukum newton 1 , hukum newton 2, energi potensial, statika, torsi, energi kinetik, gaya elastisitas (pemulih). Proses belajar ekplorasi memberikan pengalaman dalam berekplorasi dan beriteraksi demokratis, mengembangkan ide-ide kreatif, dan mampu menghubungkan pengalaman tentang fakta atau fenomena alam di lingkungan sekitar dengan pembelajaran formal yang ada di kelas. Interaksi demokratis dalam pembelajaran eksplorasi membangun kerjasama dan perilaku demokratis pada saat berdiskusi untuk memecahkan masalah secara bersama-sama. Berdiskusi bersama dengan kelompok dalam bereksplorasi dapat menyatukan pendapat, pemikiran, dan pengalaman dari setiap individu sehingga mendapatakan jawaban potensial yang lebih baik.

\section{REFERENSI}

Johari, Joy. (2013). Pengertian Eksplorasi, Elaborasi, dan Konfirmasi Dalam 
Pembelajaran. (online): (http://petirfenomenal.blogspot.com/2013/03/pengert ian-eksplorasi-elaborasi-dan.html. diakses 07 Oktober 2014 pukul 22.25 WIB).

Medellu, Ch.S. (2019). LEARNING ABOUT ENVIRONMENT: Model Of High Order Thinking Learning in Democratic Interaction. Artikel dilindungi sebagai KI no. 000138276, January 8, 2019.

Muspiroh, N. (2016), Integrasi Nilai Islam Dalam Pembelajaran IPA ( Perspektif Pendidikan Islam). Jurnal Pendidikan Islam, 28(3), 484-498.

Silangen, P. M., \& Medellu, C. S. (2019). Reflective Question in Explorative Learning: Model HOTL-DI - A and B. International Journal of Innovative Science and Research Technology, 4(11).

Usman, M. I. (2012). Model Mengajar dalam Pembelajaran: Alam Sekitar, Sekolah Kerja, Individual, dan Klasikal. Lentera Pendidikan: Jurnal Ilmu Terbiyah dan keguruan, 15(2), 251-266.

Wartono. 2003. Strategi Belajar Mengajar Fisika. Malang JICA. 